\title{
Kilka uwag na temat zeznań niewolników w procesie karnym
}

\section{Wstęp}

Problematyka efektywnej ochrony sądowej dotyczy także procesu karnego. Tematem niniejszego artykułu jest specyficzne rozwiązanie dotyczące udziału niewolników w tym typie postępowania - zakaz wykorzystywania ich zeznań na szkodę właściciela. Kwerenda źródłowa do opracowania tematu pokazała, że przeważająca część tekstów źródłowych z okresu republiki to teksty literackie. Okresu cesarstwa dotyczą z kolei głównie teksty prawnicze, dlatego wydaje się zasadne podzielenie opracowania wedle tego kryterium.

\section{Informacje wynikające z tekstów literackich}

Najwybitniejszy rzymski orator, Marek Tulliusz Cycero, poświęcił kilka fragmentów swoich pism problematyce składania zeznań przez niewolników. Chyba najciekawszy z nich pochodzi z pierwszej ważnej obrończej mowy Cycerona. Sekstus Roscjusz z Amerii został oskarżony o parricidium. Oskarżycielami byli członkowie jego rodu, którzy przejęli majątek zamordowanego, w tym wszystkich jego niewolników. Podczas rozprawy pojawiła się konieczność przesłuchania tych spośród nich, którzy towarzyszyli ofierze w chwili jej śmierci. Stanowili oni jednak własność Titusa Roscjusza, który, zgodnie ze zwyczajem, musiał wyrazić zgodę na ich przesłuchanie - i zgody tej nie udzielił.

Cic., Rosc. Am. 120: Res porro abs te eius modi postulabatur ut nihil interesset, utrum eam rem recusares an de maleficio confiterere. Quae cum ita sint, quaero abs te quam ob causam recusaris. Cum occiditur Sex. Roscius ibidem fuerunt. Servos ipsos, quod ad me attinet, neque

\footnotetext{
* Dr Elżbieta Loska - adiunkt w Katedrze Prawa Rzymskiego Wydziału Prawa i Administracji Uniwersytetu Kardynała Stefana Wyszyńskiego; e.loska@uksw.edu.pl.
} 
arguo neque purgo; quod a vobis oppugnari video ne in quaestionem dentur, suspiciosum est; quod vero apud vos ipsos in honore tanto sunt, profecto necesse est sciant aliquid, quod si dixerint perniciosum vobis futurum sit. 'In dominos quaeri de servis iniquum est.' At non quaeritur; Sex. enim Roscius reus est; neque enim, cum de hoc quaeritur, in dominos quaeritur; vos enim dominos esse dicitis.

Owa odmowa wzbudziła podejrzliwość Cycerona, przede wszystkim dlatego, że oskarżyciel powołał się na niesłuszność wykorzystywania zeznań niewolników przeciw ich właścicielowi. Orator zasadnie zdumiał się przyczyną odmowy proces toczył się wszak przeciw Sekstusowi Roscjuszowi, nie było zatem mowy o wykorzystaniu przeciw niemu zeznań jego własnych niewolników. Wysnuł zatem wniosek, jak się okazało podczas procesu uzasadniony, iż niewolnicy owi mogliby wyjawić pewne fakty niebezpieczne dla oskarżycieli. Istotną informacją wynikającą z tego fragmentu jest jednak to, że usiłowano zablokować przesłuchanie niewolników ze względu na przekonanie o niesłuszności wykorzystywania zeznań niewolników przeciw ich właścicielom.

Na kwestię wiarygodności zeznań złożonych na torturach Cycero zwrócił uwagę podczas mowy w obronie Publiusa Corneliusa Sulli:

Cic., Sull. 78: Quaestiones nobis servorum accusator et tormenta minitatur. In quibus quamquam nihil periculi suspicamur, tamen illa tormenta gubernat dolor, moderatur natura cuiusque cum animi tum corporis, regit quaesitor, flectit libido, corrumpit spes, infirmat metus, ut in tot rerum angustiis nihil veritati loci relinquatur. Vita P. Sullae torqueatur, ex ea quaeratur num quae occultetur libido, num quod lateat facinus, num quae crudelitas, num quae audacia. Nihil erroris erit in causa nec obscuritatis, iudices, si a vobis vitae perpetuae vox, ea quae verissima et gravissima debet esse, audietur.

Orator podkreślił, że obok bólu i strachu, które wzbudzane są podczas tortur, nie ma już miejsca na prawdę. W tym samym paragrafie zaznaczył, iż w przeprowadzonym postępowaniu nie uświadczy się błędu ani niepewności, jeśli tylko sędziowie wysłuchają historii życia Sulli opisanej przez przekonującego i prawdomównego świadka. Nietrudno zauważyć, że fragment ten pełen jest sarkazmu.

Nie tylko Arpinata dawał wyraz wątpliwościom związanym z przymusem uzyskiwania od niewolników zeznań na torturach. Także w źródłach prawniczych znaleźć można ślady nieufności względem tej metody pozyskiwania zeznań:

D. 48,18,1,23 (Ulp. 8 de off. procons.): Quaestioni fidem non semper nec tamen numquam habendam constitutionibus declaratur: etenim res est fragilis et periculosa et quae veritatem fallat. nam plerique patientia sive duritia tormentorum ita tormenta contemnunt, ut exprimi eis 
veritas nullo modo possit: alii tanta sunt impatientia, ut quodvis mentiri quam pati tormenta velint: ita fit, ut etiam vario modo fateantur, ut non tantum se, verum etiam alios criminentur.

Ulpian przekazał, iż konstytucje cesarskie zalecały ostrożność przy pokładaniu wiary w treść zeznań złożonych na torturach, z dwóch przeciwstawnych powodów: część osób mogła być tak odporna na ból fizyczny, że nie powiedziałaby nic, z kolei inne powiedziałyby wszystko, by tylko uniknąć bólu. Jeśli zatem prowadzący przesłuchanie trafiłby na osobę z którejś z tych grup, nie mógłby określić, która część jej zeznań odpowiada prawdzie ${ }^{1}$.

Podczas procesu w obronie Milona, oskarżonego o zabójstwo Publiusza Klodiusza, Cycero był zmuszony do odparcia argumentu oskarżycieli, którzy zarzucali Milonowi, iż wyzwolił swoich niewolników², którzy brali udział w zajściu zakończonym śmiercią Klodiusza, tylko dlatego, żeby nie mogli złożyć przed quaestio obciążających go zeznań.

\begin{abstract}
Cic., Mil. 57: Cur igitur eos manu misit? Metuebat scilicet ne indicaretur, ne dolorem perferre non possent, ne tormentis cogerentur occisum esse a servis Milonis in Appia via P. Clodium confiteri. Quid opus est tortore? quid quaeris? Occideritne? occidit. lure an iniuria? nihil ad tortorem: facti enim in eculeo quaestio est, iuris in iudicio. Quod igitur in causa quaerendum est, indagamus hic: quod tormentis invenire vis, id fatemur. Manu vero cur miserit, si id potius quaeris, quam cur partim amplis adfecerit praemiis, nescis inimici factum reprehendere.
\end{abstract}

Cycero po pierwsze wskazał na brak potrzeby powoływania niewolników Milona na świadków. Torturowani mieliby jedynie zaświadczyć o tym, że zajście, które doprowadziło do śmierci Klodiusza rzeczywiście miało miejsce, a temu przecież oskarżony nie zaprzeczał. Nie zaprzeczał także, że zabił Klodiusza. Natomiast rozstrzygnięcie, czy zrobił to zgodnie z prawem, czy też nie, nie leżało w kompetencjach prowadzącego przesłuchanie. Orator przypomniał także oskarżeniu i zebranej publiczności, że niewolnikom nie wolno było składać zeznań, które obciążałyby ich właścicieli. Zarzut oponentów był zatem całkowicie pozbawiony podstaw.

Cic., Mil. 59: De servis nulla lege quaestio est in dominum nisi de incestu, ut fuit in Clodium.

${ }^{1}$ Por. P. Garnsey. Social Status and Legal Privilege in the Roman Empire, Oxford 1970, s. 213 - autor wspomina, że była to, powszechna praktyka; szeroko na ten temat A. Triggiano, Evidence Given under Torture in Aristotle and Cicero, «TSDP» 2/2009, s. 5 i n.; dostęp do strony internetowej http://www. teoriaestoriadeldirittoprivato.com/index.php?com=statics\&option=index\&cID=81 dnia 6.12.2012.

${ }^{2}$ Asc., Mil. 39C. - żaden z niewolników, których zeznań domagali się oskarżyciele, nie znajdował się już pod władzą Milona. Prowadzący postępowanie zasugerował zatem po konsultacji z członkami trybunału, aby powołali oni na świadków dowolną liczbę niewolników strony, którą reprezentowali. Niewolnicy Klodiusza byli przesłuchiwani - Cic., Mil. 59. 
Wartość retoryczną argumentu podnosił fakt, iż tortury wobec niewolników mogły być wykorzystane przeciw ich właścicielowi w wypadku procesu dotyczącego incestum, przestępstwa, o które oskarżony był kiedyś Klodiusz o zabójstwo którego oskarżony został broniony przez Cycerona Milon.

Publiusz Klodiusz został oskarżony o incestum w 61 r. p.n.e. Powodem oskarżenia było zakłócenie przez niego obrzędów na cześć Bona Dea. Klodiusz pojawił się w kobiecym przebraniu w domu Gajusza Juliusza Cezara, ówczesnego pontifex maximus, bowiem miał tam schadzkę z jego żoną, Pompeją ${ }^{3}$. Scholiasta Cycerona poinformował, iż niewolnicy Cezara nie zostali przesłuchani tylko dlatego, że zostali alienowani i rozesłani do różnych prowincji, prawdopodobnie po to, aby nie udało się ich odnaleźć. Niewolnice żony Cezara natomiast poddane zostały torturom ${ }^{4}$. Jest to o tyle istotne, iż w przypadku skazania Klodiusza (do czego nie doszło, najprawdopodobniej niesłusznie) doszłoby do procesu Pompei, przeciw której można by wykorzystać złożone przez jej niewolnice zeznania.

Po raz kolejny kwestia zeznań niewolników pojawiła się w mowie pro Deiotaro. Król Deiotarus oskarżony został przez swojego wnuka o przygotowanie zamachu na Juliusza Cezara.

\begin{abstract}
Cic., Dei. 3: Fugitivi autem dominum accusantis et dominum absentem et dominum amicis simum nostrae rei publicae cum os videbam, cum verba audiebam, non tam adflictam regiam con dicionem dolebam quam de fortunis communibus extimescebam. Nam cum more maiorum de servo in dominum ne tormentis quidem quaeri liceat, in qua quaestione dolor elicere veram vocem possit etiam ab invito, exortus est servus qui, quem in eculeo appellare non posset, eum accuset solutus.
\end{abstract}

Ponownie przywołany został zwyczajowy zakaz wykorzystywania zeznań niewolników przeciw ich właścicielowi. Tu służył on Cyceronowi do próby obalenia oskarżenia. Orator argumentował, iż nie można wysłuchać popierającego oskarżenie zbiegłego niewolnika należącego do króla, skoro nie można by było wykorzystać złożonych przez niego na torturach zeznań ${ }^{5}$.

Od zakazu owego były jednak wyjątki. Wyjątki owe podał także Cycero we fragmencie de partitione oratoria:

Cic., Part. or. 118: (...) de nostrorum etiam prudentissimorum hominum institutis, qui cum de servis in dominos quaeri noluissent, de incestu tamen, et coniuratione quae facta me consule est, quaerendum putaverunt.

\footnotetext{
${ }^{3}$ Sch. Bob., in Clodium et Curionem, p. 20, 1.3 i n. (ed. Hildebrandt).

${ }^{4}$ Schol. Bob., in Clodium et Curionem, p. 28, 1.15 i n. (ed. Hildebrandt).

${ }^{5}$ Podobne rozwiązanie widoczne jest w reskrypcie cesarza z dynastii Sewerów - D. 48,18,1,16 tekst omówiony niżej.
} 
Orator poinformował, iż jego najroztropniejsi pobratymcy zabronili torturowania niewolników na szkodę właściciela, poza przypadkami incestu oraz sprzysiężenia. Były to wyjątki uzasadnione powagą tych przestępstw ${ }^{6}$.

Także obciążające kogoś zeznania niewolnika należącego do osoby trzeciej nie mogły być uzyskane bez zgody ich właściciela?

W okresie Republiki istniał zakaz torturowania niewolników in caput domini ${ }^{8}$. $\mathrm{Z}$ przekazów Cycerona wynika, że była to reguła wynikająca z mos maiorum. Ale czy na pewno?

\begin{abstract}
Tac., Ann. 2,30: negante reo adgnoscentis servos per tormenta interrogari placuit. et quia vetere senatus consulto quaestio in caput domini prohibebatur, callidus et novi iuris repertor Tiberius mancipari singulos actori publico iubet, scilicet ut in Libonem ex servis salvo senatus consulto quaereretur.
\end{abstract}

Opisując historię procesu Libona Druzusa, oskarżonego o próbę zamachu stanu, Tacyt wspomniał, iż zamierzano przesłuchać na torturach niewolników oskarżonego, który nie przyznawał się do winy. Przekazał także, że Tyberiusz nakazał przekazać ich własność agentowi skarbu, aby można ich było przesłuchać na niekorzyść Libona, nie naruszając postanowień dawnej uchwały senatu, która takiego działania zakazywała. Fragment $\mathrm{z}$ dzieła Tacyta zawiera jednak informację nie potwierdzoną w żadnym innym źródle. Wątpliwości co do wiarygodności przekazu Tacyta budzi też fakt, że niewolnicy mieli być torturowani $\mathrm{w}$ procesie dotyczącym spisku - a według Cycerona w tym przypadku nie było zakazu torturowania niewolników in caput domini.

Interesujące przykłady lojalności niewolników przytoczył rzymski antykwarysta okresu wczesnego pryncypatu, Valerius Maximus, w swoim dziele Facta et dicta memorabilia. Wydaje się wskazane przytoczenie tych spośród anegdot, która ma związek z postępowaniem karnym:

Val. Max. 6,8 pr. -1: Restat ut servorum etiam erga dominos quo minus expectatam hoc lau-
dabiliorem fidem referamus. 1. M. Antonius avorum nostrorum temporibus clarissimus orator
incesti reus agebatur. cuius in iudicio accusatores servum in quaestionem perseverantissime
postulabant, quod ab eo, cum ad stuprum irent, lanternam praelatam contenderent. erat
autem is etiam tum inberbis et stabat <in> corona videbatque rem ad suos cruciatus perti-

${ }^{6}$ Por. D. Liebs, Der Schutz der Privatsfäre in einer Sklavenhaltergesellschaft: Aussagen von Sklaven gegen ihre Herren nach römischem Recht, «BIDR» 83/1980, s. 150 i n.; J. MiszTAL-KoneCKA, 'Incestum' w prawie rzymskim, Lublin 2007, s. 152. Podobny argument podaje R.A. BAUMAN, Crime and Punishment in Ancient Rome, London 1996, s. 52.

7 A.H.J. Greenidge, The Legal Procedure of Cicero's Time, London 1901 (reprint 2005), s. 491.

${ }^{8}$ Por. U. Vincenti, 'Duo genera sunt testium'. Contributo allo studio della prova testimoniale nel processo romano, Padova 1989, s. 85 i n. 
nere, nec tamen eos fugitavit. ille vero, ut domum quoque ventum est, Antonium hoc nomine vehementius confusum et sollicitum ultro est hortatus ut se iudicibus torquendum traderet, adfirmans nullum ore suo verbum exiturum, quo causa eius laederetur, ac promissi fidem mira patientia praestitit: plurimis etenim laceratus verberibus eculeoque inpositus, candentibus etiam lamminis ustus omnem vim accusationis custodita rei salute subvertit. argui fortuna merito potest, quod tam pium et tam fortem spiritum servili nomine inclusit.

We fragmencie tym mowa jest o niewolniku, który miał zeznawać w procesie o stuprum przeciw Markowi Antoniuszowi. Oskarżyciele Antoniusza twierdzili mianowicie, że niewolnik ów trzymał lampę, którą przyświecał udającemu się na schadzkę właścicielowi. Jego zeznanie stanowiłoby wobec tego koronny dowód popełnienia przez Antoniusza zarzucanego mu czynu. Niewolnik, zgodnie ze zwyczajem, został wzięty na tortury, ale milczał, gdyż obiecał to swojemu właścicielowi. Fragment ten wyraźnie wskazuje na istnienie wyjątku od zakazu torturowania niewolników na szkodę właścicieli (w przeciwnym wypadku poświęcenie niewolnika Marka Antoniusza byłoby bezsensowne) ${ }^{9}$.

Kolejnym przykładem godnego podziwu oddania właścicielowi jest zachowanie niewolnika Philippusa, który miał być świadkiem w procesie przeciw swojemu właścicielowi Fulviusowi Flaccusowi. Był on torturowany ośmiokrotnie, nie wypowiedział jednak ani słowa przeciw swojemu panu. Flaccus mimo to został skazany.

Val. Max. 8,4,3: Item Fulvio Flacco causam dicente Philippus servus eius, in quo tota quaestio nitebatur, octies tortus nullum omnino verbum, quo dominus perstringeretur, emisit, et tamen reus damnatus est, cum certius argumentum innocentiae unus octies tortus exhiberet quam octo semel torti praebuissent.

Przykład ten wydaje się potwierdzać, iż zeznania niewolników nie mogły mieć roli decydującej przy rozstrzygnięciu sprawy. W przeciwnym bowiem przypadku Flaccus powinien zostać oczyszczony z zarzutów.

Filozof Seneka także zwrócił uwagę na kwestię składania zeznań przez niewolników.

Sen., Ep. 47,4: Sic fit ut isti de domino loquantur quibus coram domino loqui non licet. At illi quibus non tantum coram dominis sed cum ipsis erat sermo, quorum os non consuebatur, parati erant pro domino porrigere cervicem, periculum imminens in caput suum avertere; in conviviis loquebantur, sed in tormentis tacebant.

9 Juryści rzymscy uważali, że w procesach dotyczących stuprum torturowanie niewolników było niedopuszczalne - por. niżej. 
W jednym ze swoich listów podkreślił wagę dobrego traktowania niewolników. Filozof przypomniał, iż niewolnicy przywiązani do swoich właścicieli gotowi byli nadstawić za nich karku w niebezpieczeństwie, a także milczeli podczas tortur - nie wyjawiając tajemnic swojego pana.

\section{Informacje wynikające z tekstów prawniczych}

\section{Okres pryncypatu}

Dla prawnika jednak, również tego zajmującego się prawem antycznym, największą wartość dowodową mają teksty jurydyczne. Część z nich przekazana została w Digestach justyniańskich, zwłaszcza pod tytułem de quaestionibus.

Postępowanie dowodowe odbywało się zwyczajowo po mowach oskarżenia i obrony ${ }^{10}$. Jednym z jego etapów było często przesłuchanie świadków. Niewolnicy występujący w roli świadków musieli być poddani torturom ${ }^{11}$. Prawdopodobnie zasada ta obowiązywała także w okresie republiki, jednak nie jest to potwierdzone źródłowo. Niewolnicy nie byli świadkami godnymi zaufania, tortury miały najpewniej uprawdopodobnić ich zeznania ${ }^{12}$. Jednak omówione przykłady przekazane w tekstach literackich pokazują, że nawet zastosowanie tak drastycznego środka nie gwarantowało uzyskania od świadka prawdziwych informacji.

Tekst Ulpiana przekazuje zdanie niektórych cesarzy na temat stosowania tego środka dowodowego:

D. $48,18,1$ pr.-1 (Ulp. 8 de off. procons.): In criminibus eruendis quaestio adhiberi solet. Sed quando vel quatenus id faciendum sit, videamus. Et non esse a tormentis incipiendum et divus Augustus constituit neque adeo fidem quaestioni adhibendam, sed et epistula divi Hadriani ad Sennium Sabinum continetur. 1. Verba rescripti ita se habent: "ad tormenta servorum ita demum veniri oportet, cum suspectus est reus et aliis argumentis ita probationi admovetur, ut sola confessio servorum deesse videatur".

10 A.H.J. Greenidge, op. cit., s. 456 i n. (w szczególności s. 477); W. Kunkel, s.v. quaestio, «RE» 47/1963 szp. 764 = Quaestio [w:] Kleine Schriften zum römischen Strafverfahren und zur römischer Verfassungsgeschichte, Weimar 1974, s. 85; E. S. Gruen, Last Generation of the Roman Republic, Berkeley-Los Angeles, 1995, s. 237 i n.; B. Santalucia, Diritto e processo penale nell'antica Roma ${ }^{2}$, Milano 1998, s. 174.

${ }^{11}$ D. $22,5,22,1 ;$ C. 9,41,12; C.9,41,18; por. P.A. BRunT, Evidence given under Torture in the Principate, «ZSS» 97/1980, s. 256; O. Robinson, Slaves and the Criminal Law, «ZSS»98/1981, s. 223; A. WATson, Legal Origins and Legal Change, London 1991, s. 283; B. SANTAlucia, op. cit., s. 175; W. Litewski, Rzymski proces karny, Kraków 2003, s. 48.

12 Odmiennie: A. Watson, op. cit., s. 284 i n. 
Już pierwszy princeps zabronił rozpoczynania przesłuchania od zadawania niepotrzebnego bólu. Decyzję tę potwierdził cesarz Hadrian w reskrypcie adresowanym do Senniusa Sabinusa. Tortury niewolników powinny być stosowane dopiero wtedy, gdy podejrzany już został oskarżony, a inne zebrane dowody uprawdopodobniły już jego winę do tego stopnia, że brakuje tylko ostatecznego jej potwierdzenia przez zeznania niewolników. Kontynuację tej polityki widać także w prawie poklasycznym. Cesarze Constantinus i Constans uznali tortury za zdrożne praktyki, do których uciekać się można było w ostateczności, również w przypadku niewolników ${ }^{13}$.

Zadawanie niewolnikom bólu było dopuszczalne wyłącznie wtedy, kiedy przeciw oskarżonemu były już inne obciążające dowody. Zeznanie niewolnika złożone na torturach miało zatem stanowić ich uzupełnienie, niedopuszczalne było traktowanie go jako jedynego dowodu winy oskarżonego. Tortury w ogólności nie stanowiły odrębnego środka dowodowego, były wykorzystywane do uzyskania od świadków wiarygodnych zeznań ${ }^{14}$.

Zgoda właściciela niewolnika nie była wymagana do poddania go torturom, jeśli niewolnik ów był przesłuchiwany jako podejrzany o popełnienie przestępstwa ${ }^{15}$. Także w przypadku, kiedy niewolnik był po prostu świadkiem w procesie, nie było konieczne uzyskanie przez przewodniczącego quaestio pozwolenia na poddanie go torturom. W tym jednak przypadku właściciel mógł liczyć na rekompensatę w przypadku zmniejszenia wartości niewolnika, lub nawet jego śmierci w wyniku gorliwie przeprowadzanego postępowania dowodowego ${ }^{16}$.

Utrzymany został nadal, obowiązujący w okresie republiki, zakaz wykorzystywania zeznań niewolników przeciw ich właścicielowi ${ }^{17}$. Co więcej, wydaje się, iż ochrona osób wolnych została rozszerzona, bowiem nawet jeśli ktoś nie dysponował prawem własności niewolnika, jednak ten służył mu w dobrej wierze, zeznania wspomnianego niewolnika nie mogły być wykorzystane w sprawie zagrożonej karą główną ${ }^{18}$. Zakaz obejmował także tortury niewolników będących częścią majątku spadkowego, tak długo, jak istniały wątpliwości co do tego, kto stał się ich właścicielem ${ }^{19}$. Od czasów Sewerów ograniczenie dotyczyło również stosowania tortur wobec niewolnika będącego współwłasnością kilku osób w przypadku oskarżenia którejkolwiek z nich ${ }^{20}$.

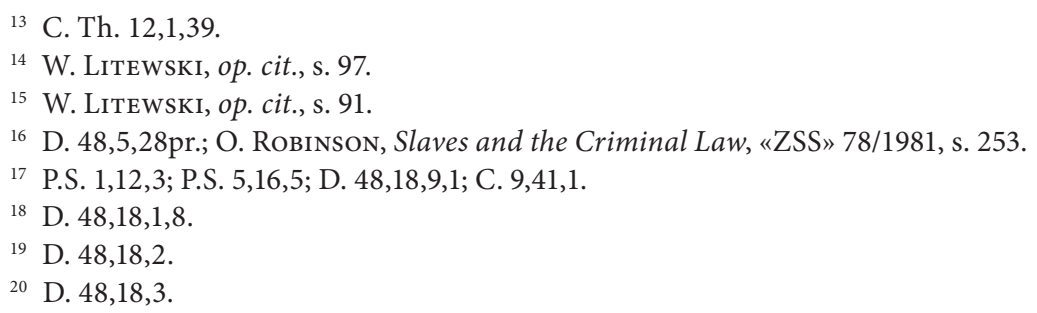


Także Septymiusz Sewer odpowiadając na pytanie Spiciusa Antigonusa przekazał swoją decyzję w kwestii dopuszczalności wykorzystywania zeznań niewolników:

D. 48,18,1,16 (Ulp. 8 de off. procons.): Item Severus Spicio Antigono ita rescripsit: „cum quaestio de servis contra dominos neque haberi debeat neque, si facta sit, dicturi sententiam consilium instruat: multo minus indicia servorum contra dominos admittenda sunt".

Reskrypt cesarski potwierdził, że nie można było dopuścić jako środków dowodowych donosów niewolników na swoich właścicieli. Uargumentował to właśnie tym, iż nie można było pozyskiwać zeznań przeciw właścicielom od niewolników na torturach, ani ich wykorzystywać, jeśli dotarły do wiadomości wydającego wyrok. Tym bardziej zatem dobrowolnie udzielone przez niewolników informacje nie mogły stanowić dowodów

Juryści dywagowali także nad sposobami obejścia istniejącego zakazu. Sytuacja, w której ktoś oferował wykupienie niewolnika, aby ten mógł zeznawać przeciw dawnemu właścicielowi, była jednak niedopuszczalna.

D. 48,18,1,18 (Ulp. 8 de off. procons.): Cum quidam deponere pretium servi paratus esset, ut servus torqueretur contra dominum, imperator noster cum divo patre suo id non admiserunt.

Ulpian przekazał, że cesarze nie dopuścili, aby ktoś zaoferował zdeponowanie sumy równej wartości niewolnika w zamian za torturowanie go przeciw właścicielowi. Jest to właściwie równoznaczne z ofertą wykupienia owego niewolnika, tudzież z całkowitym wyrównaniem szkody wynikłej z umniejszenia jego wartości na skutek przeprowadzonego postępowania dowodowego. Jaka była przyczyna tego uregulowania, trudno wyrokować, nie znamy bowiem sprawy, przy rozstrzyganiu której cesarze wydali taką decyzję. Można jedynie przypuszczać, iż chodziło o uniemożliwienie nadużyć - w przypadku dopuszczenia takiego wyjątku utrzymanie reguły o niemożności wykorzystywania zeznań niewolników przeciw ich właścicielom byłoby niemożliwe - w poważnej większości przypadków znalazłaby się „życzliwa” osoba, która wykupiłaby niewolnika, aby ten zeznawał.

W 240 roku cesarz Gordianus wydał reskrypt dotyczący możliwości wykorzystywania zeznań niewolników:

C.9,41,6 (Imp. Gordianus): Pridem placuit domestica servorum seu libertorum propriorum vel maternorum interrogatione in causis ad dominos vel patronos pertinentibus abstinendum esse, ut neque pro his neque adversus eos in capitalibus vel pecuniariis quaestionibus veritatis vim obtinere possit, quod in confessionem ab eis fuerit deductum.

Cesarz przypomniał, że już dawno temu zdecydowano, że należy się wstrzymać z przesłuchiwaniem niewolników i wyzwoleńców w sprawach dotyczących 
ich właścicieli i patronów. Powód tej regulacji był następujący: nie da się ustalić, czy to, co uzyska się w wyniku zeznań tych świadków w sprawach zagrożonych karą śmierci czy dotyczących pieniędzy, jest prawdą, czy nie - niezależnie od tego, czy byłoby to zeznanie na korzyść właściciela/patrona, czy wręcz przeciwnie.

W przypadku, kiedy doszło do przestępstwa cudzołóstwa, lex Iulia de adulteriis coërcendis przewidywała całkowicie inny tryb postępowania. Być może jednak nie rozszerzała wcale wyjątków od republikańskiej zasady - nie zezwalano na wykorzystanie zeznań niewolników przeciw panom, lecz odbierano właścicielom władzę nad nimi, czyniąc niewolników własnością publiczną.

D. 48,5,28,11 (Ulp. 2 de adult.): lubet lex eos homines, de quibus quaestio ita habita est, publicos esse (...) Ratio autem publicandorum servorum ea est, ut sine ullo metu verum dicant et ne, dum timeant se in reorum potestatem regressuros, obdurent in quaestione.

Lex Iulia nakazywała, aby niewolnicy, którzy byli przesłuchiwani w sprawach dotyczących cudzołóstwa, stawali się własnością publiczną. Ulpian podał tu ratio owego rozwiązania - przypuszczano, iż niewolnicy podlegający konfiskacie nie będą się opierać podczas przesłuchania, bojąc się wrócić pod władzę oskarżonego. Według Ulpiana niewolnicy stawali się własnością publiczną dopiero po przesłuchaniu. Oznaczało to zatem, że w tym przypadku zakaz wykorzystywania zeznań niewolników przeciw ich właścicielom został praktycznie zniesiony. Jednak, jak podkreślił P. A. Brunt ${ }^{21}$, Ulpian przekazał prawdopodobnie uregulowanie jemu współczesne, możliwe zatem, że sama lex Iulia przewidywała nabycie niewolników przez państwo przed poddaniem ich torturom ${ }^{22}$, co pozwalało zachować formalną zgodę z obowiązującą od czasów republiki regułą.

W wyjątkowych przypadkach dopuszczano wykorzystywanie zeznań niewolników przeciw ich właścicielom, a były to, tak jak w okresie republiki, crimen maiestatis i incestum. Niezmiernie interesujący jest zatem, wprowadzony w pryncypacie, zakaz stosowania tortur w procesie dotyczącym incestum:

D. 48,18,4 (Ulp. 3 disp.) In incesto, ut Papinianus respondit et est rescriptum, servorum tormenta cessant, quia et lex lulia cessat de adulteriis.

Opinia Papiniana wydaje się stać w całkowitej sprzeczności z umieszczonym przez kompilatorów w bezpośrednim jej następstwie zdaniem Marcianusa:

D. 48,18,5 (Marc. 2 inst.): Si quis viduam vel alii nuptam cognatam, cum qua nuptias contrahere non potest, corruperit, in insulam deportandus est, quia duplex crimen est et incestum, quia

\footnotetext{
21 P.A. BRUNT, op. cit., s. 256 i n.

22 Por. Dio Cass. 55,5,4 - fragment dotyczył procesu w sprawie maiestas.
} 
cognatam violavit contra fas, et adulterium vel stuprum adiungit. denique hoc casu servi in personam domini torquentur.

Jurysta przekazał, że jeśli ktoś utrzymywał kontakty seksualne z kobietą, z którą nie mógłby zawrzeć małżeństwa ze względu na pokrewieństwo, niezależnie od tego, czy była ona wdową czy mężatką, był deportowany na wyspę. Popełniał on bowiem podwójną zbrodnię: i kazirodztwo, bo zniewolił krewną w sprzeczności z prawem boskim, i adulterium lub stuprum, w zależności od tego, kim była kobieta. $\mathrm{W}$ tym wypadku, jak podał Marcianus, dopuszczalne było torturowanie niewolników w sprawie dotyczącej ich właściciela.

Rozbieżność między tymi dwoma tekstami Puliatti ${ }^{23}$ tłumaczy w sposób następujący: $\mathrm{z}$ fragmentu tego wyciąga się wniosek o tym, iż w przypadku incestu nie można było poddać niewolników torturom, ze względu na to, iż lex Iulia, która przewidywała możliwość stosowania tortur wobec niewolników w przypadku popełnienia adulterium przez ich właściciela, nie zajmowała się przestępstwem incestum. Wyjątek, który uczyniła lex Iulia w generalnym zakazie stosowania tortur wobec niewolników in caput domini, najprawdopodobniej nie rozciągał się na incestum ${ }^{24}$. Przypadek opisywany przez Marciana dotyczył jednak incestum, które stanowiło jednocześnie adulterium lub stuprum. To prowadzi do pytania $\mathrm{w}$ jakim przypadku incest może nie być równocześnie adulterium/stuprum - nie jest to jednak przedmiotem niniejszego opracowania. Rozumowanie Puliattiego potwierdzone jest przez fragment innej wypowiedzi Papiniana, zachowanej w Digestach, w księdze ad legem Iuliam de adulteriis.

D. 48,5,40,8 (Pap. 15 resp.): De servis quaestionem in dominos incesti postulatos ita demum habendam respondi, si per adulterium incestum esse contractum dicatur.

Papinian odpowiedział, że przesłuchanie niewolników z użyciem tortur przeciw ich właścicielowi oskarżonemu o kazirodztwo było dopuszczalne wtedy i tylko wtedy, jeśli to przestępstwo zostało popełnione poprzez cudzołóstwo. W przypadku samego incestu stosowanie tortur byłoby zatem zakazane.

Sytuację dodatkowo komplikuje fragment D. 48,18,17,1, również autorstwa Papiniana:

D. 48,18,17,1 (Pap. 16 resp.): Sed et in quaestione stupri servi adversus dominum non torquentur.

Z fragmentu tego jednoznacznie wynika, iż jurysta uważał za niedopuszczalne torturowanie niewolników in caput domini w przypadku przestępstwa stuprum.

\footnotetext{
23 S. Puliatti, 'Incesti crimina'. Regime giuridico da Augusto a Giustiniano, Milano 2001, s. 14.

${ }^{24}$ Por. S. Puliatti, op. cit., s. 133.
} 
Wiadomo, iż z lex Iulia de adulteriis coërcendis ścigano ów czyn, wydaje się zatem, iż należy przyjąć, iż Papinian dopuszczał stosowanie tortur wobec niewolników wyłącznie w przypadku adulterium ${ }^{25}$. Wydaje się zatem, że uważano adulterium za przestępstwo o wiele bardziej szkodliwe społecznie, niż stuprum - dlatego tylko w tym pierwszym przypadku dopuszczano pewnego rodzaju obejście zasady zakazującej torturowania niewolników na szkodę ich właścicieli ${ }^{26}$. W przypadku incestu zatem także wolno było torturować niewolników in caput domini wyłącznie wtedy, kiedy przestępstwo to było popełnione w zbiegu z adulterium ${ }^{27}$.

Interesujący wniosek z zestawienia tych fragmentów podaje J. Misztal-Konecka ${ }^{28}$. Zdaniem autorki z istnienia różnych interpretacji Marcianusa i Papiniana należy wnosić, iż w czasach republikańskich przestępstwo incestum, które dopuszczało torturowanie niewolników in caput domini, a więc to, które Cycero określił jako wyjątek od przyjętej zasady, to wyłącznie występek seksualny Westalki. Jest to wniosek bardzo prawdopodobny. Fragmenty wypowiedzi Papiniana, ta przytoczona przez Ulpiana w D. 48,18,4 i ta z D. 48,5,40,8 umieszczone zostały przez kompilatorów justyniańskich w dwóch różnych tytułach Digestów. Może to świadczyć o tym, że widzieli oni wyraźnie, iż jurysta zajmował się dwoma odrębnymi rodzajami przestępstwa incestu i to rozróżnienie zastosowali kompilując Digesta. Greenidge ${ }^{29}$ ponadto stwierdził, iż oskarżonej o incestum westalce nie wolno było wyzwolić swoich niewolników, co dodatkowo wskazuje na możliwość uzyskiwania zeznań od niewolników in caput domini w tego typu przypadkach.

Zmiany w podejściu do quaestio servorum przyniosło uchwalenie SC Silanianum $^{30}$, wprowadzając odpowiedzialność zbiorową - w przypadku śmierci właściciela torturowani byli wszyscy niewolnicy, którzy przebywali z nim pod jednym dachem lub w zasięgu jego głosu.

Od czasów Trajana niewolnicy należący do męża mogli być torturowani w sprawie dotyczącej żony ${ }^{31}$. Technicznie rzecz biorąc nie było to naruszenie zasady niemożności wykorzystywania zeznań niewolników przeciw ich właścicielowi, jednak regulacja ta wydaje się stać w sprzeczności z duchem tej zasady.

D. 48,5,28,6 (Ulp. 2 de adult.): Haberi quaestionem lex iubet de servis ancillisve eius, de quo vel de qua quaereretur, parentisve utriusque eorum, si ea mancipia ad usum ei a parentibus data sint. Divus autem Hadrianus Cornelio Latiniano rescripsit et de exteris servis quaestionem haberi.

${ }^{25}$ O.F. Robinson, The Criminal Law of Ancient Rome, Baltimore 1995, s. 55.

26 Por. J. Misztal-Konecka, op. cit., Lublin 2007, s. 153.

27 O. Robinson, Slaves..., s. 236 i n.

${ }^{28}$ J. Misztal-Konecka, op. cit., Lublin 2007, s. 154 i n.

29 A.H.J. Greenidge, op. cit., s. 378.

${ }^{30}$ Por. B. Santalucia, op. cit., s. 211; E. Loska, Obowiązek niewolników obrony swojego właściciela, s. 45 i n. i literatura tam cytowana.

${ }^{31}$ D. $48,18,1,11$. 
Zgodnie z ustawą julijską przesłuchaniu powinni podlegać wszyscy niewolnicy osoby, przeciw której toczył się proces o cudzołóstwo, niezależnie od ich płci, a także niewolnicy, będący własnością innych osób, jeśli służyli oskarżonemu czy oskarżonej. Według Ulpiana ustawa wydana za czasów Augusta wymieniała wyłącznie niewolników będących własnością osoby oskarżonej lub jej rodziców, natomiast cesarz Hadrian rozszerzył krąg osób, których niewolnicy mogli być torturowani, także na osoby spoza rodziny.

W okresie pryncypatu widoczna była zatem tendencja do odejścia od zakazu torturowania niewolników na niekorzyść ich właścicieli, uzasadniana wagą przestępstwa, o które oskarżona była osoba, przeciw której toczyło się postępowanie.

\section{Okres dominatu}

Kodeks justyniański zawiera dwa fragmenty dopuszczające wyraźnie torturowanie niewolników in caput domini w przypadku maiestas ${ }^{32}$. Pierwszy z nich pochodzi z dzieła Marcianusa, komentującego lex Iulia maiestatis:

\section{9,8,6,1: In hoc item crimine, quod ad laesam maiestatem imperatoris pertinet, etiam in caput domini servos torqueri. * Marcianus libro primo de publicis iudiciis titulo ad legem iuliam maiestatis.}

Jurysta przekazał, że w przypadku zbrodni polegającej na obrazie majestatu cesarza wolno było torturować nawet niewolników na szkodę ich właścicieli.

Drugi fragment to urywek dzieła Paulusa o postępowaniu karnym:

\section{9,8,6,4: In hac causa in caput domini servi torquentur, id est propter causam maiestatis.}

Paulus z kolei poinformował o możliwości torturowania niewolników w przypadku zbrodni maiestas, nie podkreśliwszy, że chodzi o uchybienie godności cesarskiej. Wydaje się jednak, że treść obu fragmentów z Kodeksu jest właściwie taka sama - w czasach Paulusa zbrodnia ta dotyczyła już raczej przewinienia wyłącznie w stosunku do cesarza i jego rodziny, a nie godności ludu rzymskiego, jak w okresie republiki ${ }^{33}$.

\footnotetext{
${ }^{32} \mathrm{Na}$ temat maiestas por. M. Dyjakowsкa, 'Crimen laesae maiestatis' : studium nad wplywami prawa rzymskiego $w$ dawnej Polsce, Lublin 2010; EADEM, Subsydiarne stosowanie prawa rzymskiego $w$ Polsce przedrozbiorowej na przykładzie zbrodni obrazy majestatu, «TEKA Komisji Prawniczej PAN Oddział w Lublinie», 5/2012 s. s. 61 i n.,

${ }^{33}$ Por. M. Dyjakowska, Postępowanie w sprawach o 'crimen maiestatis' w okresie republiki rzymskiej, «Zeszyty Prawnicze» 6.1/2006, s. 27.
} 
Oba fragmenty dzieł jurystów znalazły się w Kodeksie pod tytułem Ad legem Iuliam maiestatis. Po raz kolejny zatem można zauważyć, iż to doniosłość popełnianego przestępstwa stanowiła o tym, czy stosowano od dawna istniejącą zasadę, czy ustanawiano od niej wyjątek.

Informacje dotyczące opracowywanego zagadnienia zawarte są także w Kodeksie Teodozjańskim, którego tytuł 6 księgi 9 poświęcony jest właśnie pozycji niewolników w procesie karnym. Wielce wymowny jest sam tytuł tej części - Ne praeter crimen maiestatis servus dominum vel patronum libertus seu familiaris accuset - niewolnik nie mógł oskarżać swojego właściciela (ani domownik czy wyzwoleniec swojego patrona) z wyłączeniem przestępstwa zdrady stanu. Incest zatem przestał prawdopodobnie być wyjątkiem od reguły. Nie wydaje się jednak możliwe ustalenie przyczyny tej zmiany.

Ten tytuł kodeksu zawiera dwa bardzo podobne uregulowania wydane na przestrzeni kilkunastu lat przez różnych cesarzy:

\footnotetext{
C. Th. 9,6,2 (Imppp. Valens, Gratianus et Valentinianus aaa. ad Maximum pf. p.): Cum accusatores servi dominis intonent, nemo iudiciorum exspectet eventum, nihil quaeri, nihil discuti placet, sed cum ipsis delationum libellis, cum omni scripturarum et meditati criminis apparatu nefandarum accusationum crementur auctores, excepto tamen appetitae maiestatis crimine, in quo etiam servis honesta proditio est: nam et hoc facinus tendit in dominos. Dat. id. mart. Valente V. et Valentiniano aa. coss. (a. 376)
}

C.Th. 9,6,3 (Impp. Arcadius et Honorius aa. Eutychiano pf. p.): Si quis ex familiaribus vel ex servis cuiuslibet domus cuiuscumque* criminis delator atque accusator emerserit, eius existimationem, caput atque fortunas petiturus, cuius familiaritati vel dominio inhaeserit, ante exhibitionem testium, ante examinatum iudicium, in ipsa expositione criminum atque accusationis exordio ultore gladio feriatur. Vocem enim funestam intercidi oportet potius quam audiri. Maiestatis crimen excipimus. Dat. VI. id. nov. Constantinopoli, Caesario et Attico coss. (a. 397)

Obie te konstytucje, skierowane do osób pełniących urząd prefekta pretorianów, zawierały zakaz przyjęcia oskarżenia składanego przez niewolnika przeciw właścicielowi. Postępowanie na podstawie takiego doniesienia nie było wszczynane, co więcej, niewolnik karany był śmiercią. Cesarze Walens, Gracjan i Walentynian nakazywali spalenie wiarołomnego niewolnika wraz z jego doniesieniem, a cesarze Arkadiusz i Honoriusz byli nieco łagodniejsi nakazali niewolnika ściąć. Jedyny typ zbrodni, o którą bez lęku mógł oskarżyć właściciela niewolnik, to crimen maiestatis. Wyjątek ten cesarze uczynili we własnym interesie - można się domyślać, iż zakładali, że ich bezpieczeństwo warte jest więcej niż lojalność niewolnika wobec właściciela.

Widać zatem, iż w okresie dominatu nie nastąpiły żadne wielkie zmiany w sytuacji procesowej niewolników - wydaje się bowiem, że zakaz oskarżania 
właściciela nie dotyczył wyłącznie aktu wnoszenia oskarżenia. Co prawda w konstytucjach cesarskich mowa jest wprost o karanych śmiercią próbach wniesienia oskarżenia, jednak właśnie z powodu tej kary można uznać za zasadne, że nie można było wykorzystywać w ogóle zeznań niewolników przeciw właścicielowi.

\section{Zakończenie}

Pozycja niewolników w procesie karnym była niska. Należy pamiętać, iż prawo rzymskie traktowało niewolników jak rzeczy, nie jak osoby, zasadne zatem jest twierdzenie, że byli traktowani przedmiotowo. W celu uzyskania od nich zeznań należało ich poddać torturom, nawet jeśli zeznawaliby i bez nich. Do przesłuchania niewolników niezbędna była zgoda ich właściciela - właśnie dlatego, że podczas tortur mogli ulec „uszkodzeniu” albo nawet „zniszczeniu", co w oczywisty sposób zmniejszało ich wartość rynkową. Zakazane było wykorzystywanie zeznań niewolników przeciwko ich właścicielom. W sposób wyjątkowy traktowano przestępstwa incestu i zdrady stanu, kiedy środek ten był dopuszczalny, ze względu na wagę tych przestępstw.

Istnienie omawianego zakazu, niezależnie od tego, czy wynikał ona z prawa zwyczajowego, czy stanowionego, było, jak się wydaje, wyrazem podejścia Rzymian do kwestii niewolników, wyrażonej w regule, że niewolnik nie może pogorszyć sytuacji prawnej swego właściciela ${ }^{34}$. Oczywiście, kwintesencja tej zasady dotykała czynności prawnych przeprowadzanych za pośrednictwem niewolników. Nie ma jednak powodu, aby nie odnieść jej także do sytuacji, kiedy zeznanie niewolnika mogło doprowadzić do skazania jego właściciela.

\section{Literatura:}

BAUMAN R.A., Crime and Punishment in Ancient Rome, London 1996,

BRUNT P.A., Evidence given under Torture in the Principate, «ZSS» 97/1980, s. 256-265,

DYJAKOWSKA M., Postępowanie w sprawach o 'crimen maiestatis' w okresie republiki rzymskiej, «Zeszyty Prawnicze» 6.1/2006, s. 27-46,

- 'Crimen laesae maiestatis': studium nad wpływami prawa rzymskiego w dawnej Polsce, Lublin 2010,

- Subsydiarne stosowanie prawa rzymskiego w Polsce przedrozbiorowej na przykładzie zbrodni obrazy majestatu, «TEKA Komisji Prawniczej PAN Oddział w Lublinie», 5/2012 s. 60-87,

GARNSEY P., Social Status and Legal Privilege in the Roman Empire, Oxford 1970,

GREENIDGE A.H.J., The Legal Procedure of Cicero's Time, London 1901 (reprint 2005),

LIEBS D., Der Schutz der Privatsfäre in einer Sklavenhaltergesellschaft: Aussagen von Sklaven gegen ihre Herren nach römischem Recht, «BIDR» 83/1980, s. 147-189,

MISZTAL-KONECKA J., 'Incestum' w prawie rzymskim, Lublin 2007,

${ }^{34}$ D. $50,17,133$. 
KUNKEL W., s.v. quaestio, «RE» 24/1963, szp. 720-726 = 'Quaestio', [w:] Kleine Schriften. Zum römischen Strafverfahren und zur römischen Verfassunggeschichte, Weimar 1974, s. 33-110,

LITEWSKI W., Rzymski proces karny, Kraków 2003,

LOSKA E., Obowiq̨zek niewolników obrony swojego właściciela, s. 45-56,

PULIATTI S., 'Incesti crimina'. Regime giuridico da Augusto a Giustiniano, Milano 2001,

O. RoBINSON, Slaves and the Criminal Law, «ZSS» 98/1981, s. 213-254,

- The Criminal Law of Ancient Rome, Baltimore 1995,

SANTALUCIA B., Diritto e processo penale nell'antica Roma², Milano 1998,

TRIGGIANO A., Evidence Given under Torture in Aristotle and Cicero, «TSDP» 2/2009, s. 5 i n.;http://www. teoriaestoriadeldirittoprivato.com/index.php?com=statics\&option=index\&cID=81

VINCENTI U., 'Duo genera sunt testium'. Contributo allo studio della prova testimoniale nel processo romano, Padova 1989,

WATSON A., Legal Origins and Legal Change, London 1991.

\section{Streszczenie}

W starożytnym Rzymie obowiązywała zasada, wedle której podczas procesu nie można było wykorzystywać zeznań niewolników na szkodę ich właściciela. Od tej zasady już od czasów republiki przewidziane były wyjątki, w przypadku przestępstw kazirodztwa oraz spisku.

Odmienne podejście do wykorzystywania zeznań niewolników widoczne było w okresie pryncypatu. Ustawy, takie jak lex Iulia de adulteriis coërcendis, czy reskrypty cesarskie przewidywały szereg możliwości obejścia republikańskiego zakazu, bez rzeczywistego jego złamania, ani też zniesienia. Jedynie w przypadku crimen laese maiestatis wyraźnie dopuszczono torturowanie niewolników in caput domini.

W okresie dominatu wprowadzony został zakaz przyjmowania oskarżenia składanego przez niewolnika przeciw właścicielowi, wyjątkiem była wyłącznie maiestas. Oskarżający niewolnik był karany śmiercią.

Słowa kluczowe: prawo rzymskie; proces karny; niewolnicy.

\section{Some Remarks on the Slaves' Testimonies in the Criminal Trial}

\section{Summary}

In ancient Rome there was a rule that in the course of the trial the slave confession could not be used to the detriment of their owners. There have been exceptions to this rule since the time of the Republic, in the case of incest crime and conspiracy.

A different approach to the use of the testimony of slaves was visible during the Principate. Laws, such as lex Iulia de adulteriis coërcendis, or imperial rescripts, provided for a number of possibilities to circumvent the republican ban, without actually breaking it, or abolishing it. Only in the case of crimen laese maiestatis it was explicitly allowed to torture the slaves in caput domini.

During Dominate accepting the charges submitted by the slave against the owner was forbidden, excepting maiestas only. Accusing slave was punished with death.

Keywords: Roman law; criminal trial; slaves. 